\title{
FEMALE ADOLESCENTS WITH PHYSICAL DISABILITY PREPAREDNESS ON MENARCHE AT PEMBINAAN ANAK CACAT FOUNDATION, SEMARANG, CENTRAL JAVA
}

\author{
Pringga Widya), Dyah Ayu²), Isy Royhanaty²) \\ ${ }^{1)}$ Masters Program in Public Health, Universitas Sebelas Maret \\ ${ }^{2)}$ Study Program of Applied Midwifery, School of Sciences Karya Husada, Semarang
}

\begin{abstract}
Background: The gynecological health needs of girls with disabilities is an issue related to their rights as individuals. Physical and emotional changes in adolescents tends to bring more difficulties among girls with disabilities due to their compromised learning and motor abilities. This study aimed to investigate female adolescents with physical disability preparedness on menarche.

Subjects and Method: A qualitative study with phenomenology was conducted at foundation for the development of disabled children in Semarang, Central Java, from October to November 2015. The key informants were 6 quadriplegic female adolescents. the study variable was preparedness menarche in female adolescent with disability. The data were collected by in-depth interview.

Results: Thid study found that several aspects menarche preparedness in female adolescents with physical disability, included (1) understanding aspect, and (2) readiness aspect. They understand that menarche is the first bleeding from the female genitalia at the age of 10-16 years which is characterized by changes in hip and breast enlargement, and growth of armpit and genital hair. Female adolescents feel ready to face menarche.
\end{abstract}

Conclusion: Female adolescents have sufficient knowledge and readiness when facing menarche.

Keywords: female adolescent, diability, menarche

\section{Correspondence:}

Pringga Widya Pusparini. Masters Program in Public Health, Universitas Sebelas Maret. Jl. Ir Sutami 36A, Surakarta 57126, Central Java. Email: pringgawidya93@gmail.com. Mobile: +6282297585452 .

The $8^{\text {th }}$ International Conference on Public Health Solo, Indonesia, November 17-18, 2021 | 84 